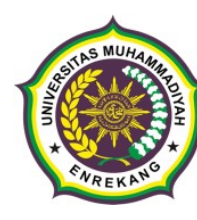

\title{
Peningkatan Kemampuan Guru Biologi dalam \\ Menyusun RPP dan Melaksanakan Supervisi \\ Klinis pada SMA Binaan Kabupaten Belu, Provinsi Nusa Tenggara Timur
}

\author{
Ulu Emanuel \\ Dosen pada Program Studi Pendidikan Bahasa Inggris \\ Fakultas Ilmu Pendidikan, Universitas Timor, Kefamenanu, Timor, NTT
}

* Corresponding Author. E-mail: ${ }^{1}$ suherieuroliner@gmail.com

\begin{tabular}{|l|l|l|}
\hline Receive: 13/02/2021 & Accepted: 23/02/021 & Published: 01/03/2021
\end{tabular}

\begin{abstract}
Abstrak
Kemampuan pengelolaan pembelajaran biologi baik meliputi perencanaan pembelajaranmaupun pelaksanaannya agar prestasi belajar peserta didik meningkat baik akademik maupun non akademik. Selain itu, kepala sekolah dan atau pengawas hendaknya selalu mengadakan supervisi klinis dengan pembinaannya secara periodik, baik yang terkait perangkat maupun pelaksanaan pembelajaran. Ada beberapa metode yang digunakan dalam pembelajaran IPA Biologi, antara lain: (a) metode ceramah, (b) metode Diskusi, (c) metode demonstrasi, (d) metode eksperimen, (e) metode karya wisata, Berdasarkan hasil penelitian dan pembahasan di atas, maka hipotesis yang peneliti ajukan, bahwa melalui supervisi klinis oleh pengawas diduga dapat meningkatkan kemampuan guru biologi dalam menyusun RPP serta pelaksanaan pembelajaran serta meningkatkan prestasi peserta didik, dapat diterima.
\end{abstract}

Kata kunci: peserta didik; RPP; Guru Biologi

\section{PENDAHULUAN}

Suatu upaya untuk meningkatkan mutu pendidikan adalah dengan cara meningkatkan mutu sumber daya manusia dan sumber daya lain yang ada di sekolah. Sebagai institusi yang paling bawah, sekolah mempunyai peranan penting untuk meningkatkan sumber daya manusia yang profesional. Dengan sumber daya manusia yang profesional diharapkan mampu meningkatkan kualitas pembelajaran. Dalam hal ini adalah kemampuan menyusun rencana pelaksanaan pembelajaran (RPP) dan pelaksanaannya yang menentukan keberhasilan peserta didik dan akhirnya berdampak pada peningkatan prestasi sekolah, baik prestasi akademik maupun non akademik. Yang selanjutnya dapat melahirkan kader - kader bangsa yang bermutu dan berdaya saing yang kuat. Berdasarkan hasil supervisi kunjungan kelas tahun pelajaran 2018/2019, diasumsikan masih didapati guru biologi dalam melaksanakan tugas pokok utamanya dalam penyusunan rencana pembelajaran dan pelaksanaan pembelajaran: 1) Bersifat tradisional, alamiah, kurang efektif dan kurang inovatif. 2) Penyusunan RPP dan pelaksanaannya kurang optimal. 3) Adanya RPP yang baik tetapi pelaksanaan tidak sesuai. 4) Adanya RPP yang kurang baik. 5) Adanya RPP yang hampir semua guru sama, karena dari MGMP atau dari salah satu penerbit. 6) Pelaksanaan pembelajaran tidak berpedoman dari RPP yang telah dibuat.

Guru dalam melaksanakan pengelolaan pembelajaran kurang memperhatikan lima tugas pokok guru, yang meliputi: menyusun program pembelajaran, menyajikan program pembelajaran, melaksanakan evaluasi hasil belajar, menganalisis hasil evaluasi belajar serta menyusun dan melaksanakan program perbaikan dan pengayaan (Depdikbud, 1994: 3).

Padahal menurut manajemen pembelajaran kelima tugas pokok di atas harus sinkron, berimbang dan terpadu. Khusus untuk penyusunan RPP dan pelaksanaannya adalah tugas pokok yang sangat esensial. Sebagai bukti yang riil hasil Ujian Nasional mata pelajaran Biologi SMA di Belu Utara tahun pelajaran 2018/2019 dengan rata-rata 8,04. Apabila dalam proses pembelajaran telah melalui perencanaan dan pelaksanaan yang matang dan lebih baik, nilai rata-rata ada kecenderungan lebih meningkat. 
Oleh karena itu, agar kemampuan penyusunan RPP dan pengelolaan pembelajaran bagi guru biologi meningkat, diperlukan adanya supervisi klinis secara terencana, terprogram dan berkelanjutan oleh pengawas sekolah. Dengan supervisi klinis baik oleh pengawas maupun kepala sekolah diharapkan penyusunan RPP akan lebih baik dan pengelolaan pembelajaran akan lebih efektif yang akhirnya berdampak pada peningkatan prestasi sekolah.

Atas pemikiran di atas, maka judul yang akan diangkat adalah, "Peningkatan Kemampuan Guru Biologi Dalam Menyusun RPP Dan Pelaksanaannya Melalui Supervisi Klinis Pada SMA Binaan di Kabupaten Belu."

Untuk memecahkan masalah tersebut di atas adalah dengan mengadakan supervisi klinis melalui tindakan observasi RPP, observasi pelaksanaan pembelajaran, wawancara dan diskusi sebelum dan sesudah observasi pelaksanaan pembelajaran serta memberikan saran dan bimbingan untuk perbaikan. Hal ini dilakukan melalui dua siklus yang terdiri atas empat tahapan, dalam masing - masing siklus terdiri perencanaan, pelaksanaan tindakan, observasi dan refleksi. Karena itu, penelitian ini bertujuan untuk mengetahui dampak supervisi klinis oleh pengawas terhadap kemampuan guru dalam penyusunan RPP dan pelaksanaan pengelolaan pembelajaran biologi, kemampuan guru setelah melakukan penyusunan perencanaan (RPP) dan melaksanakan pembelajaran yang lebih baik.

\section{KAJIAN TEORITIS}

\section{Pengertian Supervisi}

Supervisi adalah bimbingan dan pemberian bantuan profesional kepada guru, kepala sekolah dan staf sekolah ke hal-hal yang lebih teknis operasional dalam bidang pendidikan dan untuk peningkatan proses pembelajaran yang efektif, efisien, dan relevan. Tujuannya adalah agar (1) kepala sekolah, guru, dan staf sekolah lainnya terampil menjabarkan tujuan pendidikan dari yang umum menjadi lebih khusus, (2) guru dapat lebih profesional dan mau dengan ikhlas membimbing siswa-siswanya, terutama siswa yang kurang mampu, (3) guru dapat lebih profesional dan mampu menggunakan sumber-sumber pengalaman belajar, (4) guru dapat lebih profesional dapat mengadakan pendekatan keterampilan proses dan pembelajaran yang mengaktifkan siswa dengan sungguh-sungguh, (5) guru dapat lebih profesional dan terampil menggunakan alat bantu pelajaran dalam proses pembelajaran, (6) guru dapat lebih profesional dan dapat mengadakan penilaian proses dan hasil belajar siswa secara baik, (7) guru dapat lebih profesional dan dapat memanfaatkan ruang dan alat laboratorium IPA, bahasa, perpustakaan, komputer, kesenian dan olah raga serta fasilitas lain secara optimal, (8) kepala sekolah dapat merencanakan dan mengarahkan penggunaan dana yang dikelola sekolah lebih berdaya guna, hasil guna dan tepat guna, dan (9) kepala sekolah dapat lebih mampu dan mau tulus ikhlas memimpin dengan demokratis, musyawarah dan mufakat (Ditdikmenum Depdikbud, 1993: 2 - 3).

Untuk mencapai tujuan di atas, supervisi perlu dilakukan secara yang memiliki ciri-ciri antara lain: (1) direncanakan secara berencana dan kontinu, (2) sistematis, prosedural dan teknik tertentu, (3) ada instrumen untuk pengumpulan data, da (4) ada data yang obyektif dari keadaan sesungguhnya (Sukirman, 2007: 11). Supervisi ilmiah ini juga perlu dilakukan atas dasar prinsip umum dan khusus. Prinsip umum supervisi ilmiah ialah (1) supervisi harus praktis, sesuai situasi dan kondisi sekolah, (2) berfungsi sebagai sumber informasi untuk pengembangan proses pembelajaran, dan (3) dilaksanakan sesuai kurikulum yang berlaku. Sedangkan prinsip khusus yang perlu dijalankan ialah (1) sistematis, obyektif dan menggunakan instrumen, (2) kekeluargaan yaitu prinsip saling asih, asuh dan asah serta Tut Wuri Handayani, (3) kreatif yaitu dapat mengembangkan kreatifitas dan inisiatif guru dalam mengembangkan proses pembelajaran dan (4) konstruktif: harus dapat memberi saran perbaikan (Dikbud, Op. cit. 3).

\section{Supervisi Kunjungan Kelas}

Supervisi kunjungan kelas atau supervisi akademik yaitu bantuan profesional kepada guru, melalui siklus perencanaan yang sistematis, pengamatan yang cermat, dan umpan balik yang obyektif dan segera. Tujuan utama supervisi kunjungan kelas yaitu untuk meningkatkan kemampuan profesional guru dan meningkatkan kualitas pembelajaran yang baik. (Depdikbud, 1998: 114 ).

Supervisi kunjungan kelas dilaksanakan untuk memperoleh data mengenai keadaan guru. Supervisi ini berfungsi sebagai alat untuk mendorong guru agar meningkatkan cara mengajarnya dan cara belajar siswanya. Karena itu, berdasarkan kehadirannya, supervisi kunjungan kelas memiliki tiga macam, yaitu:

(1) kunjungan tanpa pemberitahuan (unannounced visitation).

Segi positifnya: supervisor dapat mengamati kondisi yang sebenarnya dan guru dapat terbiasa megajar dengan persiapan yang sebaik-baiknya. Sedangkan segi negatifnya: ada guru yang menjadi gugup dan takut nilainya tidak baik. Ada juga guru yang menjadi tidak senang/tidak simpati dengan kunjungan yang spontanitas.

(2) Kunjungan dengan memberitahu lebih dulu (announced visitation) 
Segi positifnya: teknik ini sangat tepat dan punya program yang terencana dan guru juga dapat persipan lebih baik. Segi negatifnya: dapat kemungkinan siapnya hanya saat ada supervisi saja.

(3) Kunjungan atas undangan guru (visit upon invitation)

Segi positifnya: guru ada kesadaran untuk mempersiapkan diri dan terbuka untuk diberi masukan atas kekurangan. Segi negatifnya: bisa kemungkinan timbul sikap manipulasi, menonjolkan diri sedangkan biasanya tidak berbuat seperti itu.

Selama melakukan supervisi kunjungan kelas, hal-hal yang perlu diobservasi ialah usaha serta kegiatan guru dan murid, usaha dan kegiatan antara guru dan murid dalam hubungan dengan penggunaan bahan dan alat pelajaran, usaha dan kegiatan guru dan murid dalam memperoleh pengalaman belajar, dan lingkungan sosial, fisik sekolah, baik di dalam maupun di luar ruang kelas dan faktor-faktor penunjang lainnya.

Pada hakekatnya supervisi mengandung beberapa kegiatan pokok yaitu pembinaan yang kontinyu, pengembangan profesional personil, perbaikan situasi belajar - mengajar, dengan sasaran akhir pencapaian tujuan pendidikan dan pertumbuhan pribadi peserta didik. Maksudnya, dalam supervisi ada proses pelayanan untuk membantu atau membimbing guru untuk peningkatan profesional guru sehingga situasi pembelajaran yang menyenangkan, mendorong kreatifitas siswa, mendorong siswa bereksplorasi, bereksperimentasi, melakukan aktivitas positif yang meghasilkan output yang lebih berkualitas (Sutomo, 2004: 91 - 92 ).

\section{Supervisi Klinis}

Salah satu bentuk supervisi kunjungan kelas yang populer adalah supervisi klinis. Ciriciri utamanya ialah (1) supervisi yang (bukan perintah), inisiatif berasal dari guru, (2) aspek yang disupervisi merupakan usul guru, (3) instrumen dan metoda observasi dikembangkan bersama guru dan supervisor, (4) umpan balik disampaikan segera setelah selesai observasi, (5) hasil analisis dan data hasil pengamtan didiskusikan dengan mendahulukan interpretasi guru, (6) supervisi diadakan secara tatap muka dan suasana terbuka, (7) supervisor lebih banyak mendengarkan dan menjawab pertanyaan guru daripada memberi pengarahan, (8) paling tidak ada tiga tahap yaitu pertemuan awal, pengamatan, dan pertemuan umpan balik, (9) jika ada perubahan perilaku positif sebagai hasil pengamatan supaya diberi penguatan, dan (10) kegiatan ini diadakan secara berkelanjutan (Dikmenum, 1998: 114 - 116).

Tujuan Supervisi Klinis
Supervisi klinis bertujuan untuk memperbaiki kinerja guru agar lebih profesional dalam mengelola kasus pembelajaran dan seorang guru yang disupervisi dapat melakukan perbaikan. Menurut Rachmad Sucipto (2007: 6), harapan utama dari supervisi klinis ialah guru dapat tergugah untuk melakukan perbaikan kinerjanya sendiri melalui analisis sendiri.

Ada tiga tahap dalam melakukan supervisi klinis. Pertama, tahap pertemuan awal. Pada tahapan ini, supervisor menciptakan suasana akrab dengan guru sehingga guru mau menyampaikan pendapatnya secara terbuka. Supervisor bersama guru juga membahas rencana pembelajaran yang dibuat guru untuk mengambil kesepakatan aspek mana yang menjadi fokus perhatian dalam supervisi dan menyempurnakan rencana pembelajaran tersebut. Pada akhirnya, supervisor bersama guru menyusun instrumen yang akan digunakan untuk supervisi atau memakai instrumen yang telah ada. Juga cara menggunakan dan menyimpulkannya.

Tahap kedua ialah observasi pelaksanaan pembelajaran. Dalam lekaukan supervisi, supervisor perlu memperhatikan, antara lain: tempat yang telah disepakati bersama, catatan hasil observasi yang rinci dan lengkap, harus terfokus pada aspek yang telah disepakati, membuat komentar yang terpisah dengan hasil observasi dan mencatat ucapan atau perilaku yang tidak cocok dalam proses pembelajaran.

Tahap terakhir ialah pertemuan umpan balik. Pada tahap ini diskusikan hasil observasi secara terbuka antara supervisor dengan guru. Karena itu, seorang supervisor perlu memperhatikan antara lain (a) pemberian penguatan terhadap penampilan guru sehingga tercipta suasana akrab dan terbuka, (b) pembahasan tujuan pembelajaran dan aspek pembelajaran yang menjadi fokus perhatian dalam supervisi, (c) menanyakan perasaan guru setelah proses pembelajaran. Dimulai dari aspek yang dianggap berhasil dilanjutkan yang dianggap belum berhasil. Guru supaya yang menyampaikan pendapatnya, (d) menunjukkan data observasi yang telah di analisis dan diinterpretasikan, (e) menanyakan pendapat guru tesebut, mendiskusikan dan hindari kesan menyalahkan, dan (f) secara bersama menentukan rencana pembelajaran berikutnya dan meyakinkan bahwa guru tersebut mampu memperbaiki (Depdikbud, 1998: 117).

\section{Pengelolaan Pembelajaran Yang Efektif}

Guru memiliki peran sangat penting dalam menentukan kuantitas dan kualitas pembelajaran. Oleh karena itu, guru harus merencanakan dan melaksanakan proses pembelajaran secara cermat dan sungguhsungguh sehingga siswa mendapat kesempatan 
belajar sebaik-baiknya dalam mengembangkan potensi yang dimiliki. Guru harus mampu menciptakan kondisi proses pembelajaran yang efektif. Proses pengelolaan sekolah pada umumnya dan pembelajaran pada khususnya mencakup empat tahap, perencanaan (planning), mengorganisasikan (organizing), pengerahan (actuiting), dan pengawasan (controlling) yang disebut POAC (Depdikbud, 1998: 2).

Untuk mempercepat pencapaian mutu pendidikan dan mutu pembelajaran, Dwi Cahyono (2007: 4) menyatakan bahwa hal itu memerlukan manajemen yang adaptif dan inovatif, yaitu manajemen sekolah berbasis perencanaan dengan berorientasi pada proses dengan paradigma kerja sebagai berikut: (1) input jelek melalui proses yang baik, berpeluang menghasilkan out put baik, (2) input jelek melalui proses yang jelek, pasti menghasilkan out put jelek, (3) input baik melalui proses yang jelek, hampir pasti menghasilkan out put jelek, dan (4) input baik melalui proses yang baik, berpeluang besar menghasilkan out put baik.

Menurut Moh. Uzer Usman (2003: 21 31), ada lima jenis variabel yang dapat menciptakan kondisi pembelajaran efektif, yaitu (a) melibatkan siswa secara aktif, (b) menarik minat dan perhatian siswa, (c) membangkitkan motivasi siswa, dan (d) mendorong siswa untuk melakukan sesuatu.

\section{Pendekatan dan Metode Pembelajaran IPA Biologi}

Pada pembelajaran biologi, ada beberapa pendekatan yang harus diperhatikan yaitu:

1) Pendekatan Konsep dan Pendekatan Keterampilan Proses

IPA termasuk Biologi meliputi dua hal, yaitu IPA sebagai produk dan IPA sebagai proses. Produk IPA terdiri dari fakta, konsep, prinsip, teori dan hukum, sedangkan proses IPA meliputi keterampilan dan sikap untuk memperoleh dan mengembangkan pengetahuan IPA. Keterampilan ini disebut keterampilan proses IPA sedangkan sikap-sikap itu disebut sikap ilmiah. Keterampilan proses IPA yang perlu dikembangkan dalam pembelajaran IPA yaitu: mengamati, menafsirkan pengamatan, meramalkan, menggunakan alat dan

\section{METODE PENELITIAN}

Penelitian Tindakan Sekolah ini terdiri dari dua siklus yang masing - masing terdapat empat tahap yaitu perencanaan, pelaksanaan, observasi dan refleksi.

Indikator keberhasilan penÆlitian ini dilihat dari perkembangan hasil penilaian Rencana Pelaksanaan Pembelajaran (RPP), penilaian pelaksanaan pembelajaran, nilai post test peserta didik dari siklus 1 dan siklus 2. Selain itu juga dari hasil wawancara bahan, menerapkan konsep, merencanakan penelitian, berkomunikasi, mengajukan pertanyaan.

2) Pendekatan Pemecahan Masalah

3) Perencanan pembelajaraan dengan pendekatan pemecahan masalah mirip dengan pendekatan proses metode ilmiah yaitu menggunakan keterampilan ilmiah secara urut dan lengkap.

4) Pendekatan Lingkungan

Pendekatan ini sangat mendukung pembelajaran biologi. Banyak konsep biologi yang lebih bermakna bagi siswa bila disampaikan melalui pendekatan lingkungan.

5) Pendekatan Induktif dan Deduktif

Pendekatan Induktif menekankan alur pikiran dari hal yang khusus menuju hal umum. Pendekatan deduktif menekankan alur pikiran dari hal umum diuraikan menjadi hal khusus.

6) Pendekatan Sejarah

Pendekatan ini sangat mendukung pembelajaran biologi. Banyak konsepkonsep biologi yang terjadi di alam, masa lalu merupakan hasil seleksi dan adaptasi dari organisme untuk menuju keadaan yang lebih stabil.

7) Pendekatan Pengungkapan Nilai-nilai Pendekatan ini menekankan pengajaran pada konsep - konsep atau nilai - nilai dan aplikasi dengan berorientasi pada kebutuhan masyarakat. Dengan pendekatan ini siswa merasakan adanya nilai, relevasi dan manfaat serta kedekatan belajar biologi dengan dirinya dan masyarakat sekitarnya.

\section{Metode Pembelajaran IPA Biologi}

Ada beberapa metode yang digunakan dalam pembelajaran IPA Biologi, antara lain: (a) metode ceramah, (b) metode Diskusi, (c) metode demonstrasi, (d) metode eksperimen, (e) metode karya wisata, (f) metode proyek, dan metode sosiodrama (Depdikbud, 1995: 11-37). Dalam implementasinya, penggunaan pendekatan dan metode pembelajaran IPA Biologi harus disesuaikan dengan materi pembelajaran, tujuan pembelajaran serta pengalaman belajar yang akan dicapai.

pada siklus 1 dan 2 dengan guru yang bersangkutan mengenai pendapat yang dirasakan dalam pembelajaran setelah ada supervisi dan pembinaannya.

Siklus 1

a. Perencanaan. Pada perencanaan ini terdapat kegiatan antara lain (1) Mempersiapkan instrumen yang akan dipakai dalam kegiatan supervisi antar lain: format pra observasi, format penilaian RPP, format penilaian 
pelaksanaan pembelajaran dan format post observasi; (2) Membuat jadwal supervise, dan (3) Menginformasikan jadwal supervisi ke sekolah binaan yang akan dikunjungi sesuai jadwal pelajaran yang sudah ada.

b. Pelaksanaan. Pelaksanaan supervisi dimulai dari kegiatan pra observasi, observasi RPP, observasi dalam pelaksanaan pembelajaran dan post observasi. Kegiatan praobservasi merupakan kegiatan perkenalan dan wawancara sebagai pendahuluan untuk memperlancar kegiatan observasi RPP dan pelaksanaan pembelajaran. Kegiatan ini menggunakan instrumen. Selain itu, dilakukan observasi RPP dan Pelaksanaan Pembelajaran. Kegiatan ini merupakan observasi langsung dalam situasi belajar mengajar yang sebenarnya. Tujuannya ialah untuk memperoleh data yang seobyektif mungkin sehingga bahan yang diperoleh dapat digunakan untuk menganalisis kesulitan-kesulitan yang dihadapi guru dalam usaha memperbaiki pelaksanaan pembelajaran. Terakhir ialah post observasi. Kegiatan ini merupakan pertemuan antara supervisor dan guru yang dilaksanakan setelah observasi pelaksanaan pembelajaran. Dalam pertemuan ini terjadi wawancara yang terkait dengan situasi, kekurangan dan keberhasilan proses pembelajaran yang baru selesai.

c. Observasi. Hal-hal yang diobservasi antara lain: usaha guru dan murid, kegiatan guru dan murid, penggunaan bahan dan alat pelajaran, pengalaman belajar yang diperoleh dan lingkungan sosial, fisik sekolah baik di dalam maupun di luar ruang kelas dan faktor-faktor penunjang yang lain.

Dalam memperoleh data, supervisor memperhatikan syarat - syarat sebagai berikut: (1) Situasi dalam keadaan wajar, supervisor duduk di tempat yang tidak mengganggu perhatian siswa, tidak mencampuri urusan guru yang sedang

\section{HASIL DAN PEMBAHASAN}

Setelah melalui supervisi klinis pada lima sekolah, maka supervisor memperoleh data dari masing - masing sekolah yang terdiri atas lampiran 1 (daftar pertanyaan pra observasi), lampiran 2 (lembar penilaian RPP), lampiran 3 (lembar penilaian pelaksanaan pembelajaran) dan lampiran 4 (lembar pertanyaan post observasi) serta lampiran 5 (lembar hasil post test). Pasiklus 1 merupakan penilaian terhadap RPP dan pelaksanaan pembelajaran yang belum mengajar, waktu mencatat tidak menimbulkan prasangka guru, (2) Membedakan data yang penting untuk dicatat dan yang tidak, (3) Tidak untuk mencari kekurangan, tetapi mencari cara untuk memperbaiki, (4) Perhatian utamanya kepada reaksi siswa dalam proses belajar, (5) Mengajar, waktu mencatat tidak menimbulkan prasangka guru, (6) Dapat membedakan data yang penting untuk dicatat dan yang tidak, (7) Tidak untuk mencari kekurangan, tetapi mencari cara untuk memperbaiki, (8) Perhatian utamanya kepada reaksi siswa dalam proses belajar, (9) Situasi dalam keadaan wajar, supervisor duduk di tempat yang tidak mengganggu perhatian siswa, tidak mencampuri urusan guru yang sedang mengajar, waktu mencatat tidak menimbulkan prasangka guru, (10) Membedakan data yang penting untuk dicatat dan yang tidak, (11) Tidak untuk mencari kekurangan, tetapi mencari cara untuk memperbaiki, (12) Perhatian utamanya kepada reaksi siswa dalam proses belajar, (13) Mengajar, waktu mencatat tidak menimbulkan prasangka guru, (14) Dapat membedakan data yang penting untuk dicatat dan yang tidak, dan

(15) Tidak untuk mencari kekurangan, tetapi mencari cara untuk memperbaiki.

Refleksi. Kegiatan ini merupakan tindak lanjut dari koreksi yang dibahas dalam pertemuan post observasi yang bertujuan untuk memperbaiki penyusunan perencanaan (RPP) dan pelaksanaan pembelajaran yang akan datang.।

\section{Siklus 2:}

Pada siklus 2 ini tahapannya sama dengan siklus 1 yang terdiri perencanaan, pelaksanaan, observasi dan refleksi. Tujuannya adalah untuk meningkatkan kinerja guru dalam menyusun RPP dan melaksanakan pengelolaan pembelajaran biologi setelah diadakan pemantauan, penilaian, pembinaan dan perbaikan. Melalui pembinaan dan perbaikan diharapkan prestasi belajar peserta didik pada siklus 2 lebih baik dari siklus 1.

melalui pembinaan, sedangkan pada siklus 2 merupakan penilaian terhadap RPP dan pelaksanaan pembelajaran setelah melalui pembinaan pada post observasi siklus 2 . Adapun hasil observasi dan penilaian RPP dan pelaksanaannya dalam pembelajarannya sebagai berikut:

Tabel 1

Data Hasil Observasi Supervisi Klinis

\begin{tabular}{|l|l|l|l|l|l|}
\hline No & Nama Guru & Sekolah & Kelas & S. I & S. II \\
\hline
\end{tabular}




\begin{tabular}{|c|c|c|c|c|c|c|c|}
\hline & & & & RPP & Pelaks. & RPP & Pelaks. \\
\hline 1. & $\mathrm{AP}$ & SMAN 1 Atb & XII A2 & 75 & 77.03 & 82.5 & 85.12 \\
\hline 2. & TW & SMAN 2 Atb & XI A2 & 72.5 & 65.5 & 80 & 73.33 \\
\hline 3. & FI & SMAN 1 Tastim & XII A1 & 70 & 66.67 & 75 & 77.04 \\
\hline 4. & AN & SMAN 1 Tasbar & XI A & 70 & 65.45 & 75 & 73.33 \\
\hline 5. & MS & SMAN Weluli & XI A & 63.75 & 65.45 & 71 & 72.30 \\
\hline \multicolumn{4}{|c|}{ Rata - Rata } & 70.25 & 67.81 & 76.5 & 76.22 \\
\hline
\end{tabular}

Dari data hasil di atas, jika dilihat berdasarkan skala penilaian instrumen supervisi sebagai berikut: $A=85-100, B=71$ $84, \mathrm{C}=55-70,<55=$ kurang, pada siklus 1 dari unsur RPP ada 2 sekolah kategori B dan 3 sekolah kategori C dengan rata-rata 70. 25 sedangkan pada unsur pelaksanaan pembelajaran ada sekolah kategori B dan 4 sekolah kategori C dengan rata - rata 67. 81 sedangkan pada siklus 2 pada unsur RPP; 5 sekolah berkategori B dengan rata - rata 76.75 pada unsur pelaksanaan pembelajaran; 1 sekolah kategori A dan 4 sekolah B dengan rata rata 76.23 .

Tabel 2

Data Hasil Post Test Peserta Didik

\begin{tabular}{|c|c|c|c|c|c|c|c|c|c|}
\hline \multirow{2}{*}{ No. } & \multirow{2}{*}{ Nama SMA } & \multirow{2}{*}{$\begin{array}{c}\Sigma \\
\text { Siswa }\end{array}$} & \multirow{2}{*}{ KKM } & \multicolumn{3}{|c|}{ S. I } & \multicolumn{3}{|c|}{ S. II } \\
\hline & & & & Rata2 & $\mathrm{T}$ & TT & Rata2 & $\mathrm{T}$ & TT \\
\hline 1. & SMAN 1 Atb & 44 & 75 & 74.86 & 32 & 12 & 80.66 & 44 & 0 \\
\hline 2. & SMAN 2 Atb & 44 & 63 & 68.04 & 31 & 13 & 7.075 & 43 & 1 \\
\hline 3. & SMAN 1 Tastim & 43 & 63 & 70.96 & 39 & 4 & 75.09 & 43 & 0 \\
\hline 4. & SMAN 1 Tasbar & 46 & 60 & 66.09 & 34 & 12 & 69.67 & 46 & 0 \\
\hline \multirow[t]{2}{*}{5.} & SMAN Weluli & 27 & 64 & 68.70 & 23 & 4 & 74.07 & 25 & 2 \\
\hline & & 204 & & 69.72 & 159 & 45 & 74.05 & 201 & 3 \\
\hline & & & & & $78 \%$ & $22 \%$ & & 98.5 & $1.5 \%$ \\
\hline
\end{tabular}

Selain diperoleh data yang berupa angka juga diperoleh kesepakatan antara guru dengan supervisor dalam wawancara pada post observasi yaitu ditemukan hal-hal yang merupakan kelebihan dan kekuarangan dalam penyusunan RPP dan proses pembelajaran. Hal-hal yang sudah baik para guru siap untuk melanjutkan dan menyempurnakan, sedangkan hal yang belum baik mereka berkomitmen untuk memperbaikinya. Pada prinsipnya, para guru sanggup mempersiapkan diri dengan sungguh-sungguh setiap akan masuk kelas, baik dalam menyusun RPP maupun proses pembelajaran, sehingga proses maupun hasil pembelajaran akan meningkat.

Pada tabel 2 juga menunjukkan bahwa dilihat dari KKM masing-masing sekolah binaan, dengan hasil sebagai berikut; pada siklus 1, dari 204 peserta didik yang telah memenuhi KKM= 159 (78\%), yang belum tuntas $=45(22 \%)$ sedangkan pada siklus 2, dari 204 peserta didik yang telah memenuhi $\mathrm{KKM}=201(98$, $5 \%)$ sedangkan yang belum tuntas $=3(1,5 \%)$.

Berdasarkan data yang diperoleh dari observasi baik pada RPP maupun proses pelaksanaan pembelajaran, pada tabel 1 dan 2 nilai yang diperoleh para guru mengalami peningkatan yang signifikan. Hal ini menunjukkan/membuktikan bahwa supervisi klinis beserta pembinaan oleh supervisor/pengawas berpengaruh positif terhadap penyusunan RPP dan pelaksanaan dalam pembelajaran yaitu hasil rata-rata lima sekolah yang diteliti, pada unsur RPP dari nilai 70,25 pada siklus 1 , meningkat menjadi 76,5 pada siklus 2, sedangkan dari unsur pelaksanan pembelajaran dari nilai 67,81 pada siklus 1 meningkat menjadi 76,23 pada siklus. Demikian pula jika dilihat dari hasil post test, antara pelaksanaan pembelajaran pada siklus 1 rata-rata 69,72 meningkat menjadi 74,05 pada siklus 2 .

Apabila dilihat dari aspek ketuntasan peserta didik, dari 204 peserta didik yang telah memenuhi $\mathrm{KKM}=159$ (78\%), yang belum tuntas= 45 (22\%) pada siklus 1, pada siklus 2 dari 204 peserta didik yang telah memenuhi $\mathrm{KKM}=201$ (98,5\%) yang belum $=3(1,5 \%)$.

Data ini menunjukkan bahwa setelah ada supervisi klinis maka penyusunan RPP dan pelaksanaan pembelajaran menjadi lebih baik. Yang berarti bahwa supervisi klinis dan pembinaannya sangat penting untuk dilaksanakan. Karena kegiatan tersebut mampu meningkatkan kualitas pembelajaran yang berdampak pada meningkatnya hasil belajar peserta didik. Jika dilihat dari hasil wawancara pada post test, terdapat refleksi yang merupakan kesepakatan antara guru dan supervisor yaitu yang kurang baik siap memperbaiki dan yang sudah baik siap untuk meneruskan. Sedangkan setiap akan masuk kelas para guru menyadari untuk mempersiapkan diri dengan sungguh-sungguh dan lebih baik yaitu menuju pembelajaran yang aktif, inovatif, kreatif, efektif dan menyenangkan.

Data yang diperoleh dari RPP dan pelaksanaan pembelajaran berupa kuantitatif maupun kulitatif semua mendukung bahwa supervisi klinis 
merupakan kegiatan yang sangat penting untuk dilaksanakan guna memperbaiki kualitas pembelajaran. Pada akhirnya, penyusunan RPP serta pelaksanaan pembelajaran yang baik akan menghasilkan prestasi belajar peserta didik yang baik pula. Dari data yang diperoleh sampai dengan siklus 2, belum ada seorang guru yang mempunyai nilai hasil observasi RPP yang amat baik (A) dan baru ada satu guru yang mendapat nilai A untuk pelaksanaan pembelajaran, berarti supervisi klinis dan pembinaannya tetap perlu diteruskan supaya kualitas prestasi peserta didik akan semakin meningkat.

\section{SIMPULAN DAN REKOMENDASI}

Berdasarkan latar belakang dan perumusan masalah, hasil penelitian serta pembahasan yang telah dipaparkan di atas, maka peneliti membuat simpulan bahwa dengan adanya supervisi klinis oleh supervisor, maka kemampuan guru biologi dalam menyusun rencana pelaksanaan pembelajaran (RPP) dan pelaksanaannya dalam pembelajaran di sekolah binaan di kabupaten Kudus mengalami peningkatan, yang diikuti dengan peningkatan prestasi peserta didik. Selain itu, dalam menyusun RPP dan pelaksanaan pembelajaran biologi yang telah meningkat juga diikuti perubahan sikap komitmen guru yang didasarkan pada hasil penilaian dan kesediaan guru ketika wawancara pada post observasi baik pada siklus 1 mauapun siklus 2 .

\section{UCAPAN TERIMA KASIH}

Kami ucapkan terima kasih kepada Bapak serta Ibu guru dari 17 sekolah di Kecamatan Cileunyi yang telah dengan sukarela mengisi kuisioner penelitian yang kami berikan. Kami juga perlu mengucapkan terima kasih kepada Bapak M. Ridwan Sutisna, M.Pd selaku pembimbing kami dalam pembuatan artikel ilmiah ini.

\section{DAFTAR PUSTAKA}

Arikunto, Suharsimi (et. al). (2007). Penelitian Tindakan Kelas. Semarang: PT. Bumi Aksara.

Darsono, Max. (2001). Belajar dan Pembelajaran.

Semarang: IKIP Semarang Press.

Davies, Ivor K. (1991). Pengelolaan Belajar. Jakarta: Rajawali.

Depdikbud. (1993). Supervisi Pendidikan (Penataran Calon Kepala SMP/SMA) Tingkat Nasional. Jakarta: Ditdikmenum, Ditjen Dikdasmen Depdikbud.
Depdikbud. (1995). Petunjuk Teknis Mata Pelajaran Biologi. Jakarta: Ditdikmenum Ditjen Dikdasmen Depdikbud.

Depdikbud. (1998). Panduan Manajemen Sekolah.

Jakarta: Depdikbud.

Depdiknas. (2001). Manajemen Peningkatan Mutu Berbasis Sekolah. Jakarta: Depdikbud.

Depdiknas. (2007). Pedoman Bantuan Langsung (Block Grant) Pelaksanaan Penelitian Tindakan Bagi Pengawas SMA/SMK. Jakarta: Dit. Tenaga Kependidikan Ditjen PMPTK Depdiknas.

Depdiknas. (2008). Petunjuk Teknis Penelitian Tindakan Sekolah (School Action Research) Peningkatan Kompetensi Supervisi Pengawas SMA/SMK. Jakarta: Dit. Tenaga Kependidikan DitjenPMPTK Depdiknas.

Depdiknas. (2008). Laporan Penelitian Tindakan Sekolah sebagai Karya Tulis Ilmiah Dalam Kegiatan Pengembangan Profesi Pengawas Sekolah. Jakarta: Dit. Tenaga Kependidikan Ditjen PMPTK Depdiknas.

Depdiknas. (2007). Materi: Sosialisasi dan Pelatihan KTSP, Power Point. Jakarta: Depdiknas.

Mulyasa, E. (2002). Manajemen Berbasis Sekolah.

Bandung: Remaja Rosda Karya.

Muslich, Masmur. (2007). KTSP Dasar Pemahaman dan Pengembangan. Jakarta: PT. Bumi Aksara.

Nata, Abudin. (2003). Manajemen Pendidikan. Jakarta: Kencana.

Priyatni, Anjar. (2007). Penelitian Tindakan Sekolah. Semarang: Dinas Pendidikan dan Kebudayaan.

Fathurrohman, Pupuh dan Sobry Sutikno. (2007). Strategi Belajar Mengajar. Bandung: Refika Aditama.

Sucipto, Rachmad (et. al). (2007). Supervisi Manajerial, Supervisi Akademis dan Klinis. Semarang: DinasP \& K Jateng.

Sujana, Nana. (2000). Dasar-Dasar Pendidikan BelajarMengajar. Bandung: PT. Sinar Baru

Sutarno. (2004). Manajemen Sekolah. Semarang: UPT MKK Unnes.

Syah, Muhibbin. (1996). Psikologi Pendidikan 
Suatu Pendekatan Baru. Bandung: Rosda Karya.

Wasis, Dwiyogo D. (2006). Penelitian Tindakan

\section{Untuk Memperbaiki Sekolah (School Action Research). Jakarta: Dit. Tenaga Kependidikan Ditjen PMPTK Depdiknas.}

Jurnal Edumaspul, 5 (1), Year 2021- 514

(Ulu Emanuel) 